\title{
Tip 1 Diabetes Mellitusun Nadir Rastlanan Bir Bulgusu: Diaper Dermatit
}

\author{
Zühal ÖRNEK®®, Hakan KARDEŞ®, Ömer ARMAN ๑ \\ Zonguldak Bülent Ecevit Üniversitesi Tip Fakültesi, Çocuk Sağlığı ve Hastalıkları Anabilim Dalı, Zonguldak, Türkiye \\ Bu makaleye yapılacak atıf: Örnek Z, Kardeş H, Arman Ö. Tip 1 Diyabetin Nadir Rastlanan Bir Bulgusu: Diaper Dermatit. Türk Diyab Obez 2020;2: 194-196.
}

ÖZ

Çocukluklarda en sık görülen endokrinolojik ve metabolik hastalık olan Tip 1 diyabetes mellitusunun özellikle 5 yaş altı çocuklarda sıklığının daha fazla arttığı bilinmektedir. Küçük yaştaki çocuklarda diyabetik ketoasidoz ilk başvuru şekli olması daha olasıdır. İnatçı diaper dermatit ve kandidiyazis nedeniyle tetkik edilirken Tip 1 diyabetes mellitus tanısı konulan iki yaş on aylık kız hasta sunulmuştur. Olgumuz ile klasik diyabet semptomları olmadan da başvurular olabileceği, kızlarda vulva ve vajenin yaygın tutulumunda diyabet gibi altta yatan sistemik bir hastalık olabileceğini vurgulamaya çalıştık.

Anahtar Sözcükler: Tip 1 diabetes mellitus, Diaper dermatit, Kandidiyazis

\section{A Rare Finding of Type 1 Diabetes Mellitus: Diaper Dermatitis}

\begin{abstract}
It is known that the frequency of Type 1 diabetes mellitus, which is the most common endocrinological and metabolic disease in childhood, increases especially in children under 5 years of age. Diabetic ketoacidosis is more likely to be the first application in young children. We present a two-year-old girl who was diagnosed as Type 1 diabetes mellitus while being examined for persistent diaper dermatitis and candidiasis. We tried to emphasize that our case may present without the symptoms of classical diabetes, and may be an underlying systemic disease such as diabetes in the widespread involvement of vulva and vagina in girls.
\end{abstract}

Key Words: Type 1 diabetes mellitus, Diaper dermatitis, Candidiasis

\section{GİRİş}

Diabetes mellitus, insülin sekresyonunda ve/veya insülin etkisinde bozukluğa bağlı olarak gelişen; açlik veya postprandiyal hiperglisemiyle karakterize karbonhidrat, protein ve yağ metabolizma bozukluğuna yol açan kronik bir hastalıktır.

Çocukluklarda en sık görülen endokrinolojik ve metabolik hastalık olan Tip 1 diyabetes mellitus (DM) ylllar içerisinde artış göstermektedir. Özellikle 5 yaş altı çocuklarda sıklığının daha fazla arttığı bilinmektedir $(1,2)$. Tip 1 DM’ nin erken dönemdeki klinik bulguları arasında sayılan inatçı diaper dermatite (DD) bağlı kandidiyazisi olan diyabetik ketozlu bir kız hasta sunulmuştur.

\section{OLGU}

İki yaş on aylık kız hasta yaklaşık iki haftadır olan diaper dermatit nedeniyle ilçe devlet hastanesi çocuk polikliniğine başvurmuş. Kandidiyazis düşünülüp antifungal krem kullanmasına rağmen şikayetleri düzelmemiş. İdrar yolu enfeksiyonu ekartasyonu için bakılan tam idrar tetkikinde glukoz $(++++)$ ve keton $(++)$ saptanmış. Eş zamanlı kan şekeri $518 \mathrm{mg} / \mathrm{dl}$ bulunmuş. Kan gazı bakılamaması ve ileri tetkik ve tedavisinin yapılması amacıyla hasta tip 1 DM ön tanısı ile acil servisimize sevk edildi. Hastanın sistemik sorgusunda bir aydır çok su içme, günde altı-yedi ve gece de mutlakabirkereolan bez değiştirmesi olduğu öğrenildi. İștahı son zamanlarda artmış fakat kilo kaybı olmamıştı. Öksürük

ORCID: Zühal Örnek / 0000-0001-9252-1652, Hakan Kardeş / 0000-0002-0553-7072, Ömer Arman / 0000-0003-1926-1908 
veya soğuk algınlığı semptomları, ateş, bulantı, kusma veya karın ağrısı mevcut değildi. Özgeçmişinde annesinin prenatal takibinde özellik yoktu. 33 hafta+6 günlük 1900 gr, sezeryanla doğan hasta postnatal 8 . güne kadar hastanede takip edilmiş. Bunun dışında başka bir nedenle hastanede yatışı mevcut değildi. Soy geçmişinde akrabalık yok, ailede anneannede tip 2 DM mevcut, bunun dişında özellik yoktu. Acil serviste bakılan vital bulgularında ateş: $36,7^{\circ} \mathrm{C}$, tansiyon arteriyel: 100/50 mmHg, kalp tepe atımı: $140 / \mathrm{dk}$, dakika solunum sayısı: 26/dk, $\mathrm{SpO}_{2}: \% 99$, kilo: $10.900 \mathrm{gr}$ (310 p), boy: $88 \mathrm{~cm}$ (10-25 p), baş çevresi $48 \mathrm{~cm}(10-25 \mathrm{p})$ idi. Muayenesinde genel durumu iyi, baş boyun muayenesi doğal, servikal lenfadenopatisi yok, akciğer sesleri doğal, ek ses üfürüm yok, batın muayenesi doğaldı. Dehidratasyon bulgusuna rastlanmadi. Bez bölgesinde mons pubisten perine, anüsten geçen ve sakrumda sona eren yaygın keskin sinırlı hiperemisi mevcuttu (Şekil 1). Başvuru tetkiklerinde beyaz küre $16900 / \mu \mathrm{L}$, üre: $36 \mathrm{mg} / \mathrm{dL}$, kreatinin: 0,4 mg/ $\mathrm{dL}$, sodyum: $131 \mathrm{mmol} / \mathrm{L}$, potasyum: $4,5 \mathrm{mmol} / \mathrm{L}$, klor: $98 \mathrm{mmol} / \mathrm{L}$, glukoz: $659 \mathrm{mg} / \mathrm{dl}$ idi. Venöz kan gazında $\mathrm{pH}$ : 7,47, PCO2: 28,1 mm Hg; PO2: 50,6 mm Hg ve bikarbonat: $22,9 \mathrm{mEq} / \mathrm{L}$, kan ketonu 3,1 mmol/lt, insülin: $0,74 \mu \mathrm{U} / \mathrm{ml}$, $\mathrm{HbAlc}>14,5 \mathrm{mg} / \mathrm{dl}$, anti-GAD antikoru: negatif, adacik antikoru: negatif, C-peptit: $<0,25 \mathrm{ng} / \mathrm{dl}$ saptand1. Hastada fizik muayene bulguları ve laboratuvar sonuçlarına göre insüline bağımlı DM ve diyabetik ketoz tanısı konuldu. İntravenöz sodyum klorür çözeltisi $(10 \mathrm{~mL} / \mathrm{kg})$ uyguland, daha sonra idame olacak şekilde $1 / 2$ ' lik mayi başlandı. İdrar çıkımı ardından $2 \mathrm{cc} / \mathrm{kg}$ dan $\mathrm{KCl}$ total mayisine eklendi. Genel durumu iyi olan ve asidozu olmayan hastaya 1 Ü/kg/ gün dozundan dört dozda olacak şekilde subkutan kristalize insülin başlandı. Hastanın almakta olduğu diyeti $1000 \mathrm{kcal}$ olacak şekilde dört ana öğün ve dört ara öğün olacak şekilde

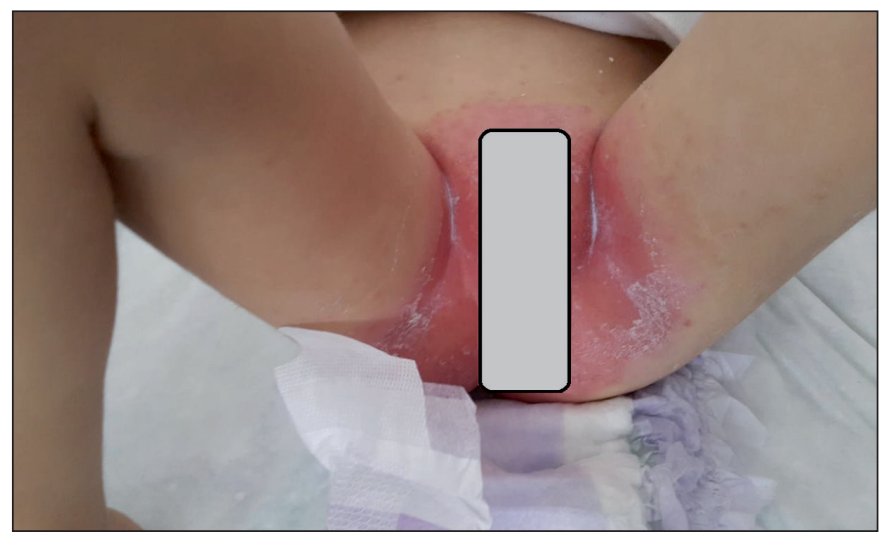

Şekil 1: Mons pubisten perine, anüsten geçen ve sakrumda sona eren yaygın keskin sinırlı diaper dermatit.

Not: Fotoğrafin bilimsel anlamda bu yazıda kullamılması için ebeveynlerinden onam alınmıştır. düzenlendi. Takibinde kan şekeri tedricen düzeldi, yatışının ikinci gününde dermatiti spontan geriledi. Hastanın kan şekeri stabil hâle geldikten sonraki tedavisinin düzenlenmesi ve eğitiminin verilmesi amaciyla çocuk endokrin bölümü olan bir merkeze yönlendirildi.

\section{TARTIŞMA}

Tip 1 DM, sıklıkla otoimmun harabiyete bağlı mutlak insülin eksikliğinin geliştiği, pankreastaki beta hücrelerinin \%85-90'dan fazlası harap olduğunda ortaya çıkan klinik bir tablodur. Yapılan epidemiyolojik çalışmalar görülme insidans ve prevalansında son yıllarda artış olduğunu göstermektedir. Özellikle 5 yaş altı çocuklarda sıklığının daha fazla arttığ bilinmektedir $(1,2)$. Hastalar çoğunlukla poliüri, polidipsi, polifaji veya iştahsızlık ve kilo kaybı gibi klasik semptomlarla başvururlar ve hiperglisemi, ketoz, ketoasidoz mevcut olabilir. Tip 1 DM' li 5 yaş altı çocuklarda diyabetik ketoasidozun başlangıç bulgusu olarak görülme oranının \%50' lerde olduğu bildirilmiştir (2- 5). Erken dönemde ise yeni başlamış enürezis, nokturi, bezlenen bebeklerde sık bez değiştirme, poliüri, polidipsi, polifaji, kilo kaybı veya kilo alımın durması, halsizlik, yorgunluk, tekrarlayan piyojenik cilt enfeksiyonları, kızlarda vajinal kandidiyazis, sünnetsiz erkek çocuklarda kandida balaniti ve inatçı DD görülebilir $(2,6)$. Vakamızdaki hastada olduğu gibi poliüri ve polidipsi gibi klasik semptomlar her zaman ilk başvuru şikayeti olmayabilir veya aileler tarafından fark edilemeyebilir. Bizim hastamıza iki haftadır süren DD nedeniyle araştırıldığı sırada tip $1 \mathrm{DM}$ tanısı konulmuştur. Diaper dermatit çocuk bezinin altında kalan bölgede nem, friksiyon, üre ve dışkı gibi faktörlerin etkisiyle gelişen irritan kontakt dermatitidir. Kandidiazis ise en sık görülen DD komplikasyonudur. Etkilenen alanlar eritemli ve keskin sınırlıdır. Lezyon sınırlarında vezikül ve püstüller şeklinde satellit lezyonlar da görülebilir. Yayma ve kültür ile kolaylıkla tanı konulur (7). Tip 1 DM' li hastalarda varolan hiperglisemi sonucunda nötrofillerin fagositoz yeteneği azalır ve kandidalar öldürülemez. Kızlarda hem kronik glikozüriden dolayı hem de fagositoz yeteneğinin azalmasından dolayı inatçı vulvovajinal kandidiyazis gelişebilir $(2,8)$.

\section{SONUÇ}

İnatçı DD' ye bağlı kandidiyazis aile tarafından fark edilebilen tip 1 DM'nin tek klinik erken bulgusu olabilir. Vulva ve vajenin yaygin tutulumunda ve uygun tedavilere rağmen düzelmediğinde diyabet gibi altta yatan sistemik bir hastalık da akla gelmelidir. Dikkatli bir anamnezle, hikayede ailelerin farkında olamadığı poliüri, polidipsi ve kilo kaybı gibi semptomlar da sorgulanmalıdır (1). 


\section{Etik Kurul Onayı}

Olgu sunumu olduğundan etik olur gerekmemiştir. Olgu fotoğrafının yayında kullanılması için ebeveynden onam alınmıştır. gerekli onam alınmıștır.

\section{Çı1kar Çatışması}

Yazarlar arasında çıkar çatışması yoktur.

Finansal Destek

Hiçbir kurum veya kuruluştan finansal destek alınmamıştır.

Yazarların Makaleye Katkı Beyanı

Fikir/kavram: Zühal Örnek, Tasarım: Zühal Örnek, Denetleme/ danışmanlık: Hakan Kardeş, Veri toplama ve/veya işleme: Ömer Arman, Analiz ve/veya yorum: Zühal Örnek, Kaynak taraması: Hakan Kardeș.

Hakem Değerlendirmesi

$\mathrm{Bu}$ yazının yayınlanması süreci kapalı-kör hakemliklerin önerileri doğrultusunda gerçekleştirilmiştir.

\section{KAYNAKLAR}

1. Sperling MA, Weinzimmer SA, Tamborlane W. Diabetes Mellitus. In Sperling M (ed). Pediatric Endocrinology. 4th ed. Philadelphia Sounders; 2014.

2. Gomez-Lopera N, Pineda-Trujillo N, Diaz-Valencia PA. Correlating the global increase in type 1 diabetes incidence across age groups with national economic prosperity: A systematic review. World J Diabetes. 2019;10(12):560-580.

3. Kocabaş A, Kocabaş BA, Karagüzel G, Akçurin S. Tip 1 Diyabetes Mellitus Olgularımızın Antropometrik ve Metabolik İzlem Özelliklerinin Değerlendirilmesi. Türkiye Çocuk Hast Derg. 2013;3:113-118.

4. Vukovic R, Jesic MD, Vorgucin I, Stankovic, Folic N, Milenkovic T, Sajic S et al. First report on the nationwide incidence of type 1 diabetes and ketoacidosis at onset in children in Serbia: A multicenter study. Eur J Pediatr. 2018; 177(8):1155-1162.

5. Bideci A, Demirel F, Çamurdan O, Cinaz P. Tip 1 diyabetli çocuklarda ilk başvuru bulgularının değerlendirilmesi. Çocuk Sağlı̆̆ı ve Hastalıkları Dergisi. 2006;49:112-116.

6. Birinci basamak sağlık kurumlarında tip 1 diyabet tanı tedavi izlem rehberi. Sağlık bakanlığı. Ankara; 2018.

7. Shin HT. Diaper dermatitis that does not quit. Dermatol Ther. 2005;18:124-135.

8. Svoren B.M, Jospe N. Diabetes Mellitus in Children. In: Kliegman M.R ed. Nelson textbook of pediatrics. 20th ed. Philadelphia Elsevier, 2016;2760-2790. 